\title{
AFRICAN STUDIES
}

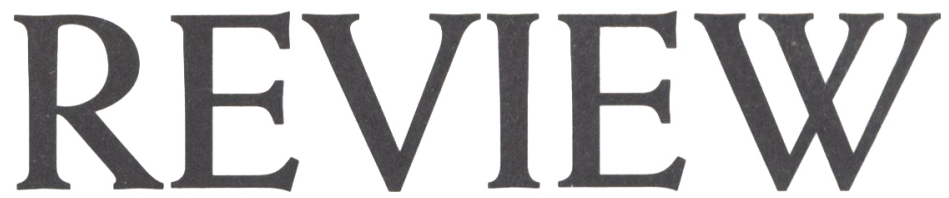

VOLUME 35, NUMBER 3 DECEMBER 1992

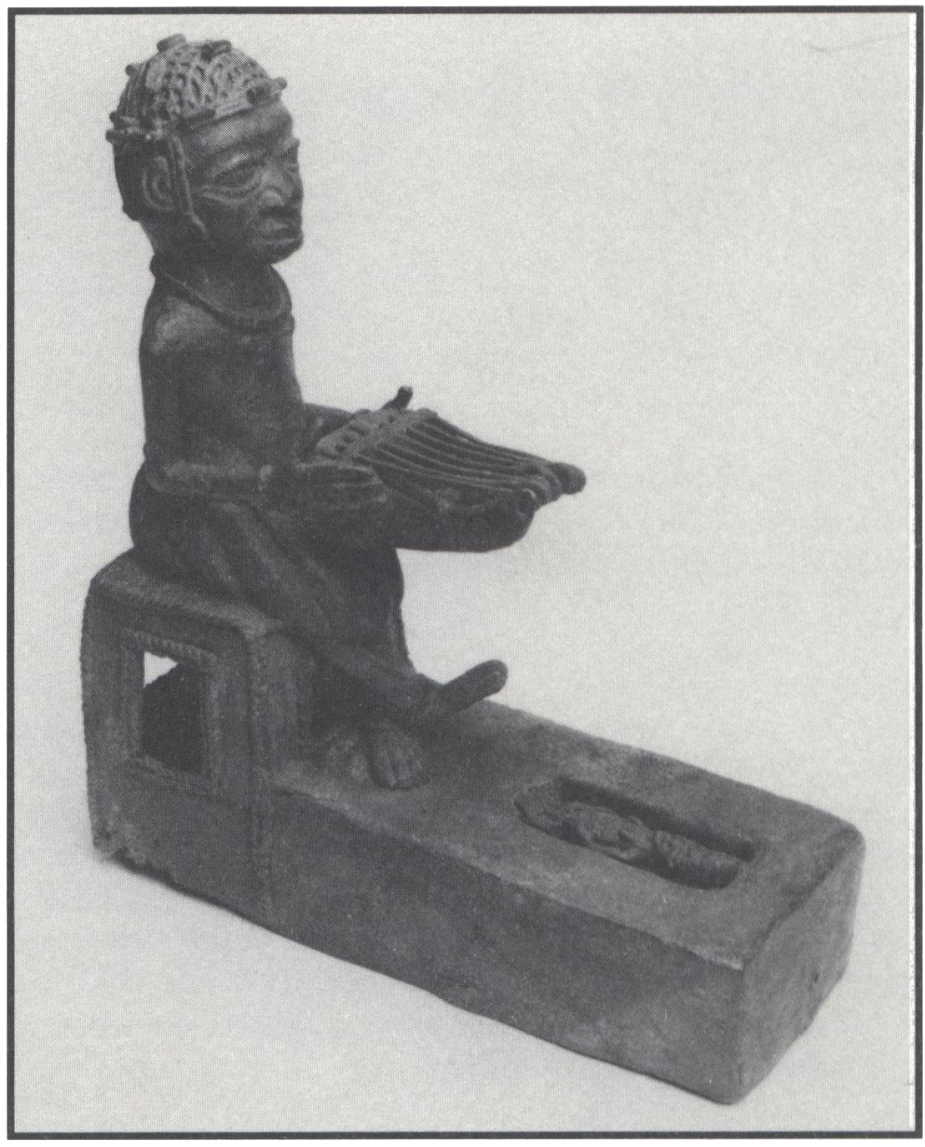

PUBLISHED BY

THE AFRICAN STUDIES ASSOCIATION 


\section{AFRICAN STUDIES REVIEW}

The Journal of the African Studies Association

EDITOR

Mark DeLancey, University of South Carolina

ASSISTANT EDITOR

Ronald Atkinson, University of South Carolina

BOOK REVIEW EDITOR

Mark DeLancey, University of South Carolina

PRODUCTION EDITOR

Rosemary Hynes

EDITORIAL ASSISTANTS

Shannon Lindsey

Peter Steen

All editorial correspondence and manuscripts should be addressed to Mark DeLancey, Editor, African Studies Review, Department of Government and International Studies, University of South Carolina, Columbia, SC 29208.

All manuscripts should be submitted in triplicate, typed double-spaced. Maps, tables, charts, and other illustrations must be camera-ready. Manuscripts should conform to the latest edition of A Manual of Style (University of Chicago Press). List notes and references at the end of the article. Manuscripts will be submitted anonymously to readers; please include a removable cover page giving name and address; title should be on the first page of text. Avoid self-identification as author throughout article. Include a 250-word abstract. The $A S R$ will only consider manuscripts that have not been published elsewhere and are not being considered by other journals.

Cover Image: Oba Ewakpe mourning the death of his wife, Iden.

Benin City, Nigeria. Circa 1960.

Brass. $27 \mathrm{~cm}$.

Kresge Art Museum

Michigan State University, East Lansing. 64.65.68.

Gift of Mr. John Hannah

Photo by Peter Glendinning, copyright 1989. 


\section{AFRICAN STUDIES}

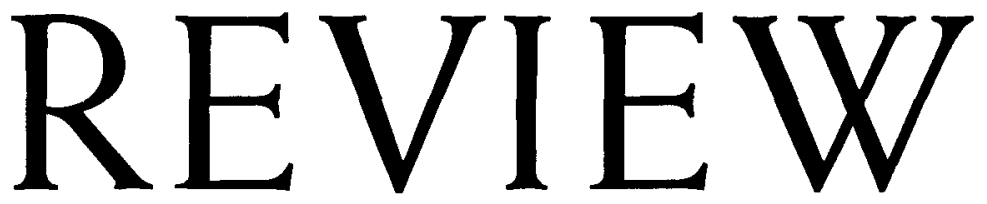

VOLUME 35, NUMBER 3 DECEMBER 1992

\section{AFRICAN STUDIES ASSOCIATION \\ Credit Union Building \\ Emory University \\ Atlanta, Georgia 30322}




\section{NOTICE TO MEMBERS}

The United States Postal System does not forward periodicals. We must receive written notification from you at least five weeks in advance of any change of mailing address. Failure to notify us of your correct mailing address will result in suspension of your membership mailings until we receive such notification. We can make address changes only when current dues are paid. Domestic claims for nonreceipt of issues must be made to the Association's office within six months of publication (overseas claims, one year). Copies of the Review damaged in the mail will be replaced without charge.

The African Studies Review is published three times a year (April, September, and December) by the African Studies Association, Credit Union Building, Emory University, Atlanta, Georgia 30322, USA. Articles in the Review represent neither the views of the African Studies Association nor those of its officers; responsibility for opinions expressed and for the accuracy of facts published rests solely with the individual authors.

O1992 African Studies Association

All rights reserved.

ISSN 0002-0206

No part of this publication may be reproduced or transmitted in any form or by any means, including photocopy, recording, or any information storage and retrieval system, without permission in writing from the publisher. Individual authors have the right to republish their articles in whole or in part without requesting permission from the Association; others desiring permission should apply to the Association. 


\section{AFRICAN STUDIES REVIEW}

VOLUME 35, NUMBER 3, DECEMBER 1992

\section{CONTENTS}

\section{ARTICLES}

Back to Democracy: Presidential Address to the 1991 Annual Meeting of the African Studies Association

Martin A. Klein

Profit versus Social Reproduction: Labor Protests in the

Sierra Leonean Iron-Ore Mines, 1933-38

Ibrahim Abdullah

Modern African Literature and Cultural Identity

Tanure Ojaide

The Absence of the Missionary in African Ethnography, 1930-65

Sjaak van der Geest and Jon P. Kirby

\section{REVIEW ESSAY AND BOOK REVIEWS}

Perspectives on South Africa's Future

J. Barron Boyd, Jr.

Religion: The Good Things in Life: A Study of the Traditional Religous Culture of the Yoruba People, Roland Hallgren (Oyekan Owomoyela), p. 114; Les Ethiopiens, Kirsten Stoffregen-Pedersen, and Les Falashas, Steven Kaplan (James Quirin), p. 115.

Literature and the Arts: Tales of Tenderness and Power and $A$ Woman Alone, Bessie Head, and $A$ Gesture of Belonging: Letters from Bessie Head, 1965-79, Randolph Vigne (Huma Ibrahim), p. 119; African Dolls for Play and Magic/Poupées africaines pour jeux et magie and Emotions in Motion/La magie de l'imaginaire, Esther A. Dagan (Robert T. Soppelsa), p. 121; Style, Classification and Ethnicity: Design Categories on Bakuba Raffia Cloth, Dorothy K. Washburn (Andrea L. Smith), p. 123.

Anthropology/Sociology: History, Power, Ideology: Central Issues in Marxism and Anthropology, Donald L. Donham (Herbert S. Lewis), 
p. 124; Power and Performance: Ethnographic Explorations through Proverbial Wisdom and Theater in Shaba, Zaire, Johannes Fabian (Oluremi Omodele), p. 128; Les Swahili entre Afrique et Arabie, F. Le Guennec-Coppens and P. Caplan, eds. (James L. Brain), p. 131.

History/Biography: American Intellectuals and African Nationalists, 1955-1970, Martin Staniland (Philip S. Zachernuk), p. 132; The Comforts of Home: Prostitution in Colonial Nairobi, Luise White (Lisa Tracey-Ritchie), p. 134; Asante and the Dutch 1744-1873, Larry W. Yarak (Roger B. Beck), p. 136; Black, French and African: A Life of Leopold Sedar Senghor, Janet G. Vaillant (Davidson Nicol), p. 138.

International Relations: Peacemaking in Civil War: International Mediation in Zimbabwe, 1974-1980, Stephen John Stedman, Humanitarian Emergencies and Military Help in Africa, Thomas G. Weiss, and Conflict and Intervention in Africa: Nigeria, Angola, Zaire, Herbert Ekwe-Ekwe (Raymond W. Copson), p. 140.

Development and Political Economy: Trade and Development in SubSaharan Africa, Jonathon Frimpong-Ansah, S. M. Ravi Kanbur, and Peter Svedberg, eds. (Carl C. Mabbs-Zeno), p. 142; The Political Economy of Poverty, Equity and Growth: Malawi and Madagascar, Frederic L. Pryor (Donald L. Sparks), p. 144; The Political Economy of Ethiopia, Marina Ottaway, ed., Ethiopia: Failure of Land Reform and Agricultural Crisis, Kidane Mengisteab, and Environment, Famine, and Politics in Ethiopia: A View from the Village, Alemneh Dejene (Robert E. Mazur), p. 146; Hydropower Development in West Africa: A Study in Resource Development, Joseph A. Sarfoh (Nurudeen B. Akinyemi), p. 149; Harvests under Fire: Regional Co-operation for Food Security in Southern Africa, Carol B. Thompson (Douglas G. Anglin), p. 150.

Health: Women and Health in Africa, Meridith Turshen, ed. (Daphne Williams Ntiri), p. 152; Plural Medical Systems in the Horn of Africa: The Legacy of "Sheikh" Hippocrates, Leendert Jan Slikkerveer (Pamela De Largy), p. 153.

Sudan: The Waters of the Nile: An Annotated Bibliography, Robert O. Collins, Imperial Sudan: The Anglo-Egyptian Condominium, 1934-56, M. W. Daly, Sudan: State and Society in Crisis, John, O. Voll, ed., and Sudan after Nimeiri, Peter Woodward, ed. (Ismail Abdullah), p. 156; Soldiers, Traders and Slaves: State Formation and Economic Transformation in the Greater Nile Valley 1700-1885, Janet J. Ewald, Religion and Custom in a Muslim Society: The Berti of Sudan, Ladislav Holy, and Culture and Change along the Blue Nile: Courts, Markets, and Strategies for Development, Lina Fruzzetti and Akos Ostor (Ismail Abdullah), p. 161. 


\section{CONTRIBUTORS}

IBRAHIM ABDULLAH teaches African history at Illinois State University. He is currently completing a manuscript entitled "Working Class Experience in Colonial Sierra Leone, 1884-1945."

JON P. KIRBY is both a missionary and an anthropologist and has lived in Ghana since 1972 . He studied religion among the Anofo of northern Ghana. He is now director of the Tamale Institute of Cross Cultural Studies.

MARTIN KLEIN teaches African history at the University of Toronto. He has recently edited Breaking the Chains: Slavery, Bondage and Emancipation in Africa and Asia (Madison: University of Wisconsin Press, forthcoming) and is now working on a study of slavery and French colonial rule in West Africa. He served as president of the African Studies Association 1990-91.

TANURE OJAIDE has published six collections of poetry and has won important poetry prizes. He has published many articles on African literature and has a forthcoming book on the poetry of Wole Soyinka. A Nigerian, he currently teaches African literature and art at the University of North Carolina at Charlotte.

SJAAK VAN DER GEEST is a cultural anthropologist at the University of Amsterdam. He did fieldwork in Ghana (1970-73) and Cameroon (1980). His most recent research focuses on social and cultural aspects of medicine. 


\section{Re-entry Grants for African Scholars Pursuing Education Research}

This grants program is designed to assist in the professional re-establishment of talented African scholars who are returning from doctoral studies abroad and have a research interest in issues related to the revitalization and development of education in sub-Saharan Africa.

All proposed projects must include an explicit and substantial focus on female school participation as part of the set of educational issues to be examined.

Applicants may submit research proposals prior to or within one year of returning to their Africa-based institutions. Grants are made to the scholar, but the proposal must be endorsed by the African institution where the applicant will be a full-time staff member. Also required are: two letters of recommendation from academic supervisors at the institution where the candidate carried out doctoral study; postgraduate transcripts; and a resume.

There are no deadlines for submission of proposals. For a full description of the program, write to:

Scholars on Education Re-Entry Program The Rockefeller Foundation 1133 Avenue of the Americas

New York, New York 10036 USA

OR

Scholars on Education Re-Entry Program The Rockefeller Foundation

P.O. Box 47543

Nairobi, Kenya 